\title{
Health and Demographic Surveillance Systems (HDSS) Asia Network Meeting
}

Meeting Report

5 March 2020, Kuala Lumpur, Malaysia

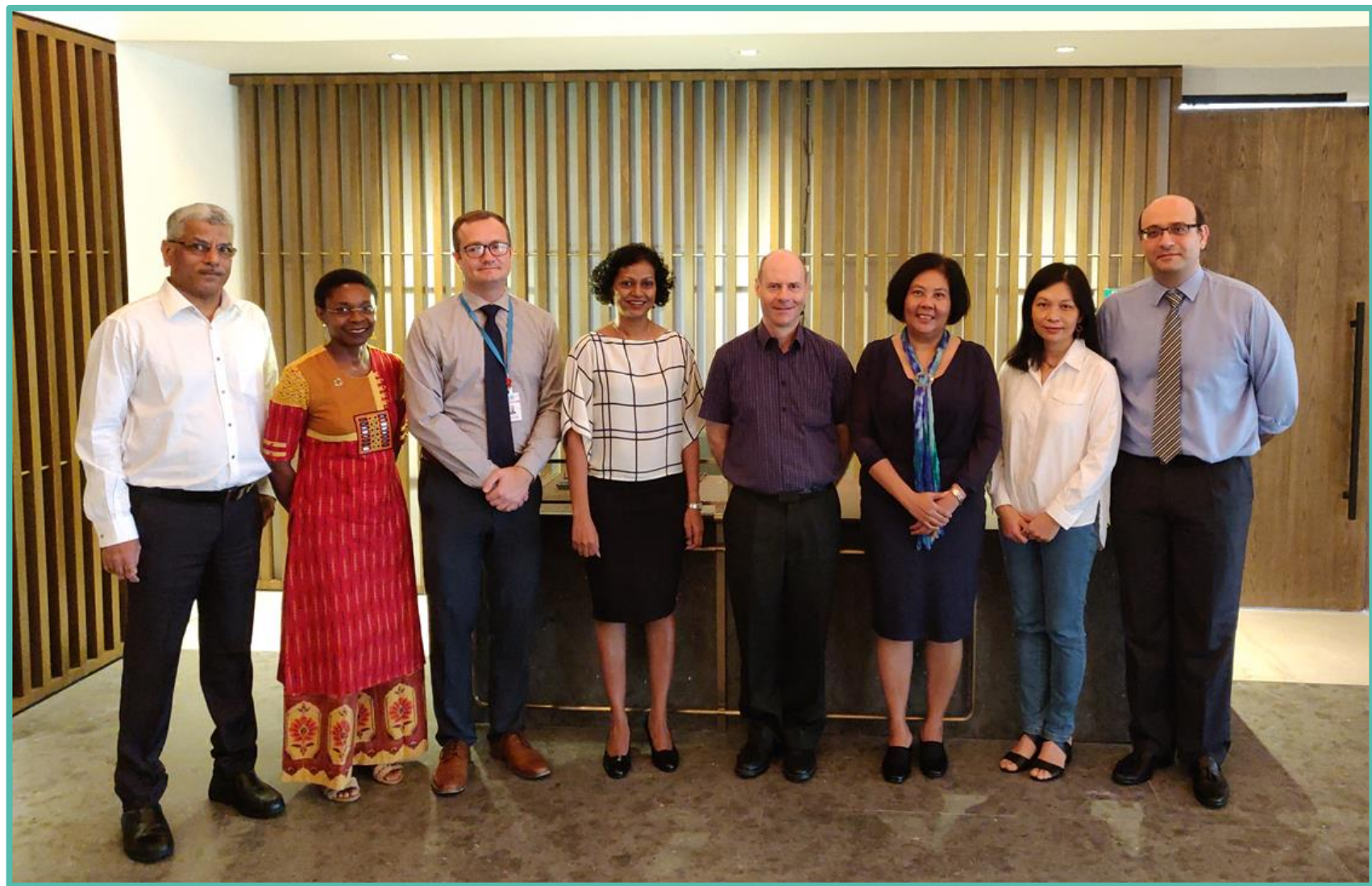

\section{Partners}
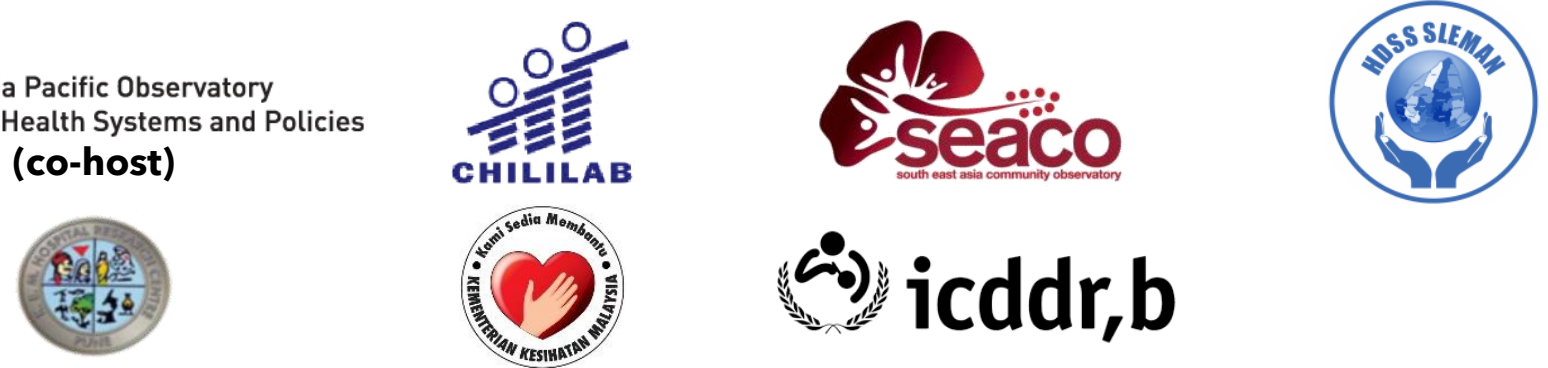

(o) icddr,b 


\section{Aim}

To bring together representatives of HDSS sites from Malaysia, Viet Nam, India, Bangladesh, and Indonesia for the first HDSS Asia Network meeting. To reflect upon the importance of HDSS Network in Asia and to explore means in strengthening regional collaborations. All attendees are part of the working group for the formulation of the HDSS Asia Network.

\section{Summary}

- The working group has aligned on the values and urgency to establish an HDSS Asia Network, focusing on South-South collaboration

- The working group leverage the many important lessons learnt from the INDEPTH Network for this meeting

- Action plans include timeline and scope of work, available in section 5.0 


\section{Agenda}

\begin{tabular}{|c|c|c|}
\hline Time & Activity & Chair \\
\hline 8.30 & \multicolumn{2}{|l|}{ Registration } \\
\hline 9:00 & $\begin{array}{l}\text { Welcome } \\
\text { - Prof. Pascale Allotey - Director UNU-IIGH } \\
\text { - Dr. Nima Asgari-Jirhandeh - Director APO } \\
\text { Prof. Tin Tun Su - Director SEACO, Monash University } \\
\text { Malaysia }\end{array}$ & \multirow[t]{2}{*}{ Pascale Allotey } \\
\hline 9.20 & Introductions and expectations & \\
\hline 9.30 & $\begin{array}{l}\text { Background to meeting } \\
\text { - Daniel Reidpath - Senior Director of Health Systems and } \\
\text { Population Health - icddr,b } \\
\text { - Discussion }\end{array}$ & Daniel Reidpath \\
\hline 10.00 & $\begin{array}{l}\text { Overview of HDSS Sites } 20 \text { minutes each } \\
\begin{array}{l}\text { - } \\
\text { - }\end{array} \text { Strengile } \\
\text { - } \text { Weaknesses } \\
\text { 1. Prof TinTin Su (SEACO Malaysia) }\end{array}$ & $\begin{array}{l}\text { Nirmala } \\
\text { Devarajan }\end{array}$ \\
\hline 10.20 & \multicolumn{2}{|l|}{ Coffee break } \\
\hline 10.40 & $\begin{array}{l}\text { 2. Dr. Sanjay Juvekar (Vadu HDSS) } \\
\text { 3. Prof Hoang Van Minh (Chililab HDSS) } \\
\text { 4. Dr Fatwa Sari Tetra Dewi (Indonesia) } \\
\text { 5. Dr S.M. Manzoor Ahmed Hanifi (Matlab Bangladesh }\end{array}$ & \multirow[t]{2}{*}{$\begin{array}{l}\text { Nirmala } \\
\text { Devarajan }\end{array}$} \\
\hline 12.00 & APO and UNU-IIGH perspectives on HDSS & \\
\hline 12.30 & \multicolumn{2}{|l|}{ Lunch } \\
\hline 13.30 & $\begin{array}{l}\text { Value of Asian Network - Round Table Discussion to address: } \\
\text { - Value to sites } \\
\text { - Value to region and countries } \\
\text { - Value to funders and external stakeholders } \\
\text { - Constitution, governance (drawing on lessons from } \\
\text { INDEPTH Network) }\end{array}$ & $\begin{array}{l}\text { Nima Asgari- } \\
\text { Jirhandeh }\end{array}$ \\
\hline 14.45 & $\begin{array}{l}\text { Next steps } \\
\text { - Data collaboration } \\
\text { - Health systems collaboration } \\
\text { - Research collaboration } \\
\text { - } \text { Trality assurance } \\
\text { - } \text { Strategic relationships and resource mobilization. }\end{array}$ & Daniel Reidpath \\
\hline 15.45 & Close & \\
\hline
\end{tabular}




\section{Meeting Attendance}

\section{In Attendance}

\section{Dr. Nima Asgari-Jirhandeh}

Director, Asia Pacific Observatory on Health Systems and Policies (APO)

\section{Prof. Pascale Allotey}

Director, United Nations University - International Institute for Global Health (UNU-IIGH)

\section{Prof. Daniel Reidpath}

Senior Director, Health Systems and Population Studies, International Centre for Diarrhoeal Disease Research, Bangladesh (icddr,b)

\section{Prof. Tin Tin Su}

Director, South East Asia Community Observatory (SEACO)

\section{Dr. Nirmala Devarajan}

Director, Quality Assurance and Compliance, Monash University Malaysia

\section{Prof. Sanjay Juvekar}

Officer in Charge, Vadu Rural Health Program, India

\section{Dr. Quyen Tu Bui}

The Chi Linh Health and Demographic Surveillance System (CHILILAB HDSS), Viet Nam

\section{Dr. Michael Penkunas}

Research Fellow, United Nations University - International Institute for Global Health (UNU-IIGH)

\section{Dr. Feisul Idzwan b. Mustapha}

Deputy Director, NCD, MOH Malaysia

\section{Dr. Fatwa Sari Tetra Dewi*}

Sleman Health and Demographic Surveillance System (HDSS), Universitas Gadjah Mada, Yogyakarta, Indonesia

\section{Dr. S.M. Manzoor Ahmed Hanifi*}

Matlab HDSS of ICDDR,B, Bangladesh

\section{Programme Support (from UNU-IIGH)}

Vithiya Sathivelu

Suzainur K. Abdul Rahman

Derrick Z Chan 


\section{Full Record}

\subsection{Introduction}

Prof. Allotey opened the meeting by welcoming attendees to Kuala Lumpur, and to the HDSS Asia Network Meeting. She spoke about the overarching objectives of the meeting, emphasising that the goal was to conclude with specific directions in moving forward.

Co-host, Dr. Nima of Asia Pacific Observatory on Health Systems and Policies, echoed Prof. Allotey on the importance of HDSS bodies from Asia coming together. He talked about the prospects of using data to bridge gaps in evidence and health policies, as well as to develop a regional understanding of health issues.

Prof. Tin Tin Su of SEACO, Monash credited Prof. Reidpath for his early intentions of forming an HDSS Asia Network. She also thanked the UNU-IIGH programme team for overseeing the logistics of this meeting, and the other attendees for joining the meeting.

Next, Prof. Allotey sought introductions from all attendees along with their expectations of the meeting.

\begin{tabular}{|c|c|c|}
\hline Name & Institute & Expectations/Indications \\
\hline Dr. Fatwa & $\begin{array}{l}\text { Sleman Health and } \\
\text { Demographic Surveillance } \\
\text { System (HDSS), Universitas } \\
\text { Gadjah Mada, Yogyakarta, } \\
\text { Indonesia }\end{array}$ & $\begin{array}{l}\text { - Increase capacity building } \\
\text { - Identify ways to improve the } \\
\text { - } \text { administration of data collection } \\
\text { - Financing of HDSS }\end{array}$ \\
\hline Dr. Hanifi & $\begin{array}{l}\text { Matlab HDSS of icddr,b, } \\
\text { Bangladesh }\end{array}$ & $\begin{array}{l}\text { - Explore ways to use longitudinal data } \\
\text { for policy developments }\end{array}$ \\
\hline Dr. Penkunas & UNU-IIGH & $\begin{array}{l}\text { - To learn more about the network and } \\
\text { its goals } \\
\text { - Understand the data being collected } \\
\text { and their potential } \\
\text { - Identifying capacity building } \\
\text { opportunities; e.g., being open to } \\
\text { have students onboard to investigate } \\
\text { these data } \\
\text { - To work collaboratively on south- } \\
\text { south engagements under IIGH's } \\
\text { Pillar } 3 \\
\text { - To develop knowledge products that } \\
\text { would inform decisions in policy } \\
\text { making }\end{array}$ \\
\hline Prof. Sanjay & Vadu Rural Health Program & $\begin{array}{l}\text { - To identify lessons learnt from } \\
\text { INDEPTH Network } \\
\text { - To see to the Asia Network's } \\
\text { sustainability }\end{array}$ \\
\hline
\end{tabular}




\begin{tabular}{lll}
\hline Name & Institute & Expectations/lndications \\
\hline Dr. Quyen & CHILILAB HDSS & To position CHILILAB as part of the \\
& & network \\
& & To identify opportunities for \\
& collaboration \\
& & To share available data; e.g., to \\
& & inform policy development \\
\hline Dr. Devarajan & Monash/SEACO & To see SEACO collaborate with \\
& & 'sister' sites across the Asia region \\
& & - To build capacity \\
& & - To explore data sharing \\
\hline
\end{tabular}

Prof. Reidpath discussed the background of the meeting. He began by listing the advantages for having an HDSS Asia Network, taking the idea from the SEACO's advisory meeting a step further. The INDEPTH Network can be used as a point of reference to examine what has worked and what has not. Examples shared by attendees were the absence of effective governance, Asia members were less represented (attributed to the geographical location), its work tends to gravitate towards Africa, there are strict criteria to be part of the network, and so on. The vision stated was to take those lessons learnt from the INDEPTH Network, and bring together Asia HDSS sites to benefit from those past experience.

Key takeaway:

- Knowing the value and relevance of the work (e.g., the value of data)

- Recognising the potentials of historical data (often underutilised)

- Funding dilemma: not enough money for retrospective analyses to build upon prospective data collection

- Have a sense of the governance structure

- Know the stakeholders involved

- Re-thinking the relationship with the INDEPTH Network (elements of moving forward together as (a new) HDSS Asia Network is being established)

- The need to work with the local authorities/ministries: i.e., to avoid duplication of work/data observed

- Recognising that HDSS Asia Network would further help contextualise (health) issues within the region

\subsection{Overview of HDSS Sites}

This session was chaired by Dr. Nirmala which saw representatives presenting their respective HDSS site based on the framework below followed by Q\&As.

(a) History of the surveillance system

(b) Types of data collected, source, and storage

(c) Population distribution

(d) The team

(e) Strengths and weaknesses of the surveillance system

(f) Organisation partners 
Refer to PowerPoint decks for details:
(a) SEACO HDSS, Malaysia
(b) Vadu HDSS, India
(c) CHILILAB HDSS, Viet Nam
(d) Sleman HDSS, Indonesia
(e) icddr,b, Bangladesh

\subsection{APO and UNU-IIGH perspectives on HDSS}

\section{APO}

- Many overlaps in the work across HDSS sites discussed; these are good from a problem standpoint but focal points are needed

- Strategic viewpoint: what would the network do if the report of surveys is different than what the government stated (inconsistent findings)?

- How to convey narratives effectively to policymakers?

- Think of comparability of data/indicator for HDSS network: making sense of upcoming collaborations

\section{UNU-IIGH}

- The validity of HDSS data is important: community engagement is constant. Segamat is a small part of the population, but by far it is the richest data that represents the local population (referring to SEACO)

- Caution that the while HDSS (i.e., SEACO) has the potential to answer certain questions but need to recognise that the answers may not be generalised for the state/country population

- National data may not make sense on primary health care delivery because it is a highly contextualised issue

- We need to be valuing different data because of the people we are serving

- Data could be used to challenge presumptions of (national) health policies and add value to the policy-making agenda 


\subsection{Value of Asia Network - Round Table Discussion}

This session was led by Dr. Nima of APO. An overview was provided by Dr. Nima on how APO can add value to the Network in Asia:

- APO can be thought of as a platform: i.e., publishing cross country work

- APO to review its budget: (1) actual work; (2) publishing

- A plus point is that there is an internal review panel, especially to look at proposals for quality assurance

- APO focus now: 1) Urban health outcomes, 2) Primary Healthcare, 3) Diabetes \& TB comanagement, and 4) Antimicrobial resistance (AMR)

- APO's 2021 stream: Urban Health, demographical change - at least for the next 4 years in conferences

- Suggestions for network engagement strategies: (1) conference; (2) room for side meetings (preconference)

- Future engagement may look at WHO's Primary Health Care Performance Initiative (PHCPI)

- Next steps: attendees have agreed on some good ideas - to get proposals sorted out for funding

4.1. Value to sites

- There is a need for a shared framework in methodology: types of data, fieldwork training, analytical science, and publications

- Mapping exercise for existing data across sites and perform cross-site analysis

- Recognising variant in governance; e.g., from the community to government policies

- HDSS Asia sites may leverage on shared funding

- To sustain resources and capacity building (wary of one-off workshops): one suggestion was to develop online courses - this is especially advantageous where meet up is not possible; focus on developing young scientists

- To accelerate outputs from sites there needs to be a translation to policy (i.e., evidence/ journal publications)

- The initial funding agenda should focus on the power of 'coming together' to formulate collective intentions/plans

- Sites could focus on outputs together; i.e. writing and co-supervising

- In the interest of time, the network could do things concurrently; i.e., strategising its approach and scale-up

- Discuss and learn from challenges experienced by each site

- South-South collaboration is a topic of interest

4.2. Value to region and countries

- Essential to compare steps taken by different country on health surveillance

- Finding out what evidence is available/published so far (e.g., from the INDEPTH Network)

- Important to have knowledge products

- Think about whether the network is to look at influencing regional agenda, though it might be difficult without regional evidence

- Therefore, it is important to look at how HDSS sites could harmonise on data of 'regional importance'

- The European governments were said to have more engagements where they would highlight evidence required in certain areas

- Digital health platforms can be leveraged for impact 
4.3. Value to funders and external stakeholders

- It is advantageous to know the primary interest of donors

- Funders seek data; it is important to know which data can be made available

- Based on experience: funders would typically insist on data

- HDSS Data scoping options, going back (a) 5 years or (b) 20 years back; but first, the working group must recognise the pros and cons. Whether they are relevant to show impact and that funders would have their preference as well

\subsection{Constitution, governance (drawing on lessons from INDEPTH Network)}

- Data management policies (governance) should be followed; ethical review boards, typically within universities could be involved in making sure that only aggregated data were shared (no personal information can be identified)

- Attendees could all look into respective ethical processes when it comes to taking other institute's data

- Reference: Data Safe Haven - tech that can ensure the protection of data 


\subsection{Next steps}

\section{Actions Actor}

5.1. Data collaboration

- Each institute to share selected data on Excel sheets for scoping purpose

- Mapping of data and identifying areas of interest

\subsection{Health systems collaboration}

- Memorandum of Understanding

- Memorandum of Agreement

\section{Prof. Tin Tin Su}

\section{Timeline}

2 Weeks

$20^{\text {th }}$ March 2020

$\begin{aligned} & \text { Prof. Reidpath, to draft } \\ & \text { MOU month to circulate draft } \\ & \text { MOU }\end{aligned}$

Prof. Sanjay (secondary) Expectations: 6 months to to support/follow through sign (early September 2020) End March/ Early April 2020

- Concept note to SIDA* on prospective work: a harmonised proposal (from harmonised data sets) to go for a grant

\section{Prof. Reidpath}

Dr. Penkunas offered support on prospective work

- To be sent to all for review

5.4. Quality assurance

$\mathrm{N} / \mathrm{A}$

N/A

- Data governance: discussed in general terms

5.5. Training / Fellowship opportunities

N/A

N/A

- Discussed in general terms

5.6. Strategic relationships and resource mobilisation

- Linked to item 5.1

- Review of sites' output - an analysis of past data for gap analysis

(scoping/data paper - identifying potential areas of research)

- Formulation of research questions

${ }^{1}$ The Swedish International Development Cooperation Agency (Sida) is Sweden's government agency for development cooperation that strive to reduce world poverty by allocating resources and knowledge with the goal of making a difference for people in Africa, Asia, Europe and South America. 
Report was prepared by Derrick Chan

Editorial inputs were provided by Suzainur KA Rahman

https://doi.org/10.37941/MR-F/2020-1

CUnited Nations University International Institute for Global Health (UNU-IIGH) 2020

Some rights reserved. This work is available under the Creative Commons AttributionNonCommercial ShareAlike 3.0 IGO licence (https://creativecommons.org/licenses/by-ncsa/3.0/igo/)

Under the terms of this licence, you may copy, redistribute, and adapt the work for noncommercial purposes, provided the work is appropriately cited, as indicated below. In any use of this work, there should be no suggestion that UNU-IIGH endorses any specific organisation, products, or services. The use of the UNU-IIGH logo is not permitted. If you adapt the work, then you must license your work under the same or equivalent Creative Commons licence. If you create a translation of this work, you should add the follow disclaimer along with the suggested citation: "This translation was not created by the United Nations University International Institute for Global Health (UNU-IIGH). UNU-IIGH is not responsible for the content or accuracy of this translation. The original English edition shall be the binding and authentic edition."

Suggested citation. Health and Demographic Surveillance Systems (HDSS) Asia Network Meeting Meeting Report. UNU-IIGH: 2020 (10.37941/MR-F/2020-1). Licence: CCBY-NC-SA 3.0 IGO

Sales, rights, and licensing. To submit requests for commercial use and queries on rights and licensing, please contact iigh-info@unu.edu.

Third-party materials. If you wish to reuse material from this work that is attributed to a third party, such as tables, figures or images, it is your responsibility to determine whether permission is needed for that reuse and to obtain permission from the copyright holder. The risk of claims resulting from infringement of any third party-owned component in the work rests solely with the user.

General disclaimers. The designations employed and the presentation of the material in this publication do not imply the expression of any opinion whatsoever on the part of UNU or UNUIIGH concerning the legal status of any country, territory, city or area or of its authorities, or concerning the delimitation of its frontiers or boundaries. Dotted and dashed lines on maps represent approximate border lines for which there may not yet be full agreement.

The mention of specific tools, companies, or of certain manufacturers' products does not imply endorsement or recommendations by UNU or UNU-IIGH in preference to others of a similar nature that are not mentioned.

All reasonable precautions have been taken by UNU-IIGH to verify the information contained in this publication. However, the published material is being distributed without warranty of any kind, either expressed or implied. The responsibility for the interpretation and use of the material lies with the reader. In no event shall UNU or UNU-IIGH be liable for damages arising from its use.

\section{Printed in Malaysia}

